\title{
カルマン症候群における
}

嗅裂部の電子顕微鏡的観察

\author{
五十嵐 淑晴・岡 良巳・石塚 洋一*
}

\section{Electron Microscopic Observations of \\ the Nasal Olfactory Area in Kallmann Syndrome}

\author{
Yoshiharu Igarashi and Yoshimi Oka \\ (Teikyo University) \\ Yoichi Ishizuka \\ (Teikyo University Mizonokuchi Hospital)
}

A 52-year-old man with Kallmann syndrome (olfacto-genital dysplasia) had abnormally low serum gonadotropic hormone and testosterone levels. The LH-RH test revealed little response.

Small pieces of mucosa were experimentally resected from the olfactory area of both sides of the nasal cavity and examined morphologically with scanning and transmission electron microscopes. Ciliated cells, mucus secreting (goblet) cells, and basal cells, which are characteristic epithelial cells of the respiratory system, were densely distributed, but no olfactory epithelial cells or their neural processes were seen. In this case, these observations indicate a complete olfactory deficiency caused by agenesis of at least the peripheral portion of the neural olfactory system. Further investigations are necessary to determine the relationship between the pathology and the degree of olfactory disturbance in Kallmann syndrome.

Key words: Kallmann syndrome, olfactory area, electron microscopic study

Kallmann 症候群とは低ゴナドトロピン性性 腺機能低下と嗅覚の低下または脱失を伴なった 疾患で, 別名 olfacto-genital dysplasia とよ ばれ，1856年 Maestre de San Juan ${ }^{1)}$ が, 次 いで1944年 Kallmann ら²が本症候群を詳細に まとめ発表した比較的頻度の少ない疾患であ る（表 1 ）。視床下部の異常に起因する低ゴナ ドトロピン性性腺発育不全と嗅球形成不全とが
解剖学的連絡を介し，互いに影響をおよぼした あのといわれるが, 剖検数は少なく両者の因果 関係や嗅球形成不全についても多くは知られて いない.

このたび, われわれは泌尿器科でホルモン療 法中の Kallmann 症候群の一例を診察する機 会を得, その鼻科学的検査および嗅裂部試験切 除粘膜の電顕による検索をおこなった。 その観

帝京大学医学部耳鼻咽喉科学教室

*帝京大学溝口病院耳鼻咽喉科 
察結果を報告し，あわせて若干の考察を加えて みた。

症例 52歳, 男性,

主訴：anosmia

家族歴: 不妊のため 1 年で離弤. 父母, 兄 弟，姉妹，親戚には性腺機能不全および唤覚晢 失のものは存在せず.

既往歴：19歳一肺結核で S M, P A S 治療.

5 年間で完治.

41歳一慢性副舅腔炎に対し右上顎洞篩骨洞根 本術をうけた。

51歳一二次性性腺機能低下に対して男性ホル モン作用を有する蛋白同化ホルモンの内服を 1 年間続行中。

現病歴：吴いの感覚は子供の頃より全くな く，はっきりした発現時期は不明．鼻閉はない が，小学生の頃より粘椆な膿性鼻漏が量的な変
動を伴ないながら続いている。身長は $167 \mathrm{~cm}$, 体重は64kg と平均レベルにあり，また体型の異 常や gynecomastia もない. 男子外性器は小 児程度の発達で，左殬丸は陰囊内に触せず。耽 毛はきわめて溥く微量. 外性器の発達不全や嗅 觉異常に対する劣等感を常に意識しており，精 神科的には不安神経症之診断されていた。一般 検査および内分泌検查所見は表 2 のとおりで ある．鼻内所見では鼻粘膜は全体にピンク色で あり，以前手術をうけた右中鼻道はやや浮腫状 を呈する屯，嗅裂は㕕く開いている，左鼻腔は 中鼻道，搝裂はやや狭くなっているが，鼻茸形 成はない，雨鼻腔とも粘液とともに少量の膿性 痂疲形成がみられた。嗅裂部をとおる鼻の前額 断層レントゲン写真でも嗅裂の開存程度がよく わかり，また篩板の欠損ならびに鼻腔一頭蓋内 腔との異常交通などの奇形も認められない。頭

表 I 性腺発育不全症の病態

\begin{tabular}{|c|c|c|c|c|c|c|}
\hline & 身 辰 & $\begin{array}{l}\text { gonado- } \\
\text { tropins }\end{array}$ & $\begin{array}{l}\text { LH-RH test } \\
\text { (LHの反応) }\end{array}$ & $\begin{array}{l}\text { testo- } \\
\text { sterone }\end{array}$ & karyotype & 咱 觉 \\
\hline I. 思添期荤発狂 & 低 & 正掌化遅延 & 正漟化遅延 & 低 $\rightarrow$ 正 & 正 & 正 \\
\hline 脳腫揚 & 発沽不全 & 低 & 低反応ないし無反応 & 低 & 正 & 正 \\
\hline $\begin{array}{l}\text { ゴナドトロピン巣独 } \\
\text { 欠損症: }\end{array}$ & 正: & 低 & 低反文伈ないし無反応 & 低 & 正 & 正: \\
\hline Kallmann 症候群 & 正 & 低 & 低反応ないし無反文応 & 低 & 正 & $\begin{array}{l}\text { 低下また } \\
\text { は消失 }\end{array}$ \\
\hline $\begin{array}{l}\text { 特発性汎下垂体機能 } \\
\text { 低下症 }\end{array}$ & 低 & 低 & 低父応ないし無反応 & 低 & 正. & 正 \\
\hline III. 原発性:性腺機能不全 & & & & & & \\
\hline Turner 症候群 & 低 & 高 & 仕齢に比し過剩反応 & 低 & $\begin{array}{l}\mathrm{XO} \text { and } \\
\text { variant }\end{array}$ & 正 \\
\hline Klinefelter 症候群 & 正～高 & 高 & 思春期に過剩反応 & 低あるいは正 & $\begin{array}{l}\text { XXY or } \\
\text { variant }\end{array}$ & 正 \\
\hline $\begin{array}{l}\mathrm{XX} \text { or } \mathrm{XY} \\
\text { 性腺発青不食症 }\end{array}$ & 正 & 高 & 午齢に比し過剩反応 & 低 & $X X$ or $X Y$ & 正 \\
\hline
\end{tabular}


部 C Tでは喚球を映しだすのは困難であるが， 頭蓋底部には異常所見はなく, 脳萎縮むみられ ない（図 1 ）。静脈性嗅覚検査では無反忘であ
った。これらの所見や検査から神経性嗅覚障害 と診断し，この障害が嗅球形成不全にもとづく 嗅裂部神経感覚上皮の形成不全によるものか否

表 2 一般検査およびホルモン検査所見

末梢血

$\begin{array}{lc}\text { ヘマトクリット } & 45.6 \% \\ \text { 血色素量 } & 14.7 \mathrm{~g} / \mathrm{dl} \\ \text { 赤血球数 } & 488 \times 10^{4} \\ \text { 白血球数 } & 6500 \\ \text { 血小板数 } & 30.5 \times 10^{4} \\ \text { 白血球百分摔 } & \\ \text { 好中球 } & \\ \text { 桿状 } & 4 \% \\ \text { 分葉 } & 50 \% \\ \text { 好酸球 } & 3 \% \\ \text { 好塩基球 } & 0 \% \\ \text { 単球 } & 6 \% \\ \text { リンパ球 } & 37 \% \\ \text { 尿 } & \\ \text { 反応pH } & 4.8 \\ \text { 比重 } & 1.016 \\ \text { 蛋白 } & (-) \\ \text { 糖 } & (-) \\ \text { ウロビリノーゲン } & (-) \\ \text { 呼吸機能検査 } & \text { 正常 } \\ \text { 鼻腔抵抗検査 } & \text { 正常 } \\ \text { 脳波検查 } & \text { 異常なし }\end{array}$

\section{生化学}

総ビリルビン

$0.4 \mathrm{mg} / \mathrm{dl}$

直接

$0.1 \mathrm{mg} / \mathrm{dl}$

GOT

$27 \mathrm{U}$

G P T

$23 \mathrm{U}$

L D H

$289 \mathrm{U}$

T T T

1. $3 \mathrm{U}$

$\mathrm{ZTT}$

4. $3 \mathrm{U}$

総蛋白

$7.8 \mathrm{~g} / \mathrm{dl}$

A/G

1.36

尿素窒素

10. $5 \mathrm{mg} / \mathrm{dl}$

クレアチニン

1. $2 \mathrm{mg} / \mathrm{dl}$

$\mathrm{Na}$

$142 \mathrm{mEq} / \mathrm{l}$

$\mathrm{K}$

$4.5 \mathrm{mEq} / \mathrm{l}$

$\mathrm{Cl}$

$101 \mathrm{mEq} / 1$

血中ホルモン

テストステロン

(正常值

$50 \mathrm{ng} / \mathrm{dl}$

$275 \sim 1100 \mathrm{ng} / \mathrm{dl}$ )

L H-R Hテスト

反応不良

HCGテスト

骨年令

染色体

感度不良

遅滞 10歳代半ば

$46 \mathrm{X} \mathrm{Y}$

静脈性唤覚検査

反応なし
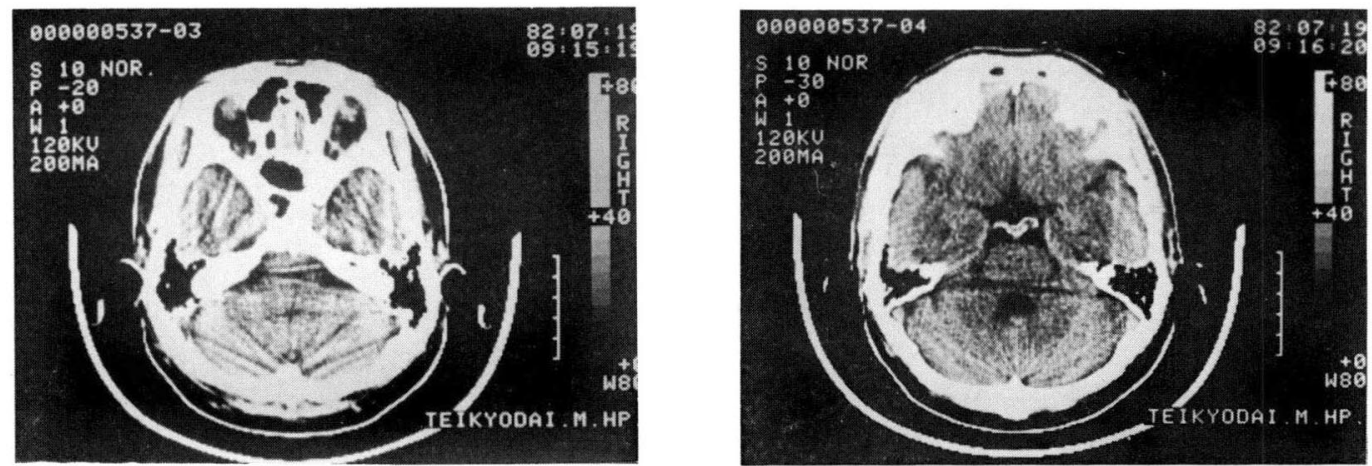

図 I 頭部 C T

頭蓋底部には骨欠損や異常はなく, 脳萎縮もみとめない。 
かを検索するため，本人の同意の屯とに両側嗅 裂最深部より $3 \times 3 \mathrm{~mm}$ の粘膜学試験切除, 採取 した。各々 2 分割し， $2.5 \%$ グルタールアルデ ヒド $(0.1 \mathrm{M}$ リン酸緩衝液) で 2 時間一次固定老 ほどこし，次いで $1 \%$ オスミウム酸溶液で 2 時 間二次固定老おこなった。 その後，走査電湿用 資料作製のため，一部は上昇エタノール系列で 脱水の後, 䣷酸イソアミルで処理し, 臨界点乾 燥，イオンコーティングの後，日立HH S - 2 $\mathrm{R}$ 走査型電子顕微鏡で観察した。また，透過電 顕用資料作製は，二次固定後，ブロック染色を おこなった。ささら，水洗，脱水，エポン樹脂 包埋後, 標本横断面の $1 \mu \mathrm{m}$ 切片を作製し， 卜 ルイジンブルーで染色しながら穆裂部より採取 した粘膜全体の検索をおこなった。

この標本作製中, 順次超薄切片を作製し, 酢 酸ウランと鉛による二重染色を戈こない，日立
HS - 9 透過型電子顕微鏡で観察した。 嗅裂部粘膜の観察結果

嗅裂部粘膜の表面からの観察では嗅小胞や嗅 毛はごこにもなく，かわって呼吸部でみられる 瀻毛之杯細胞が密に分布していた（図2）。粘 膜槽本の横断面でむ嗅細胞一支持細胞などの嗅 覚神経感覚上皮は全く観察されず，走査電顕所 見に一致して, 緎毛細胞・杯細胞・基底細胞加 ら成る呼吸上皮系の細胞配列を見るのみであっ た（図 3 ）。ほかに，散在性に慢性副鼻腔炎に 伴なう好中球，形質細胞からなる炎症性細胞浸 潤を上皮細胞下部に認めた。繊毛細胞の繊毛の 横断面は, 典型的な microtubule $の 9+2$ の 構造やアームを示しており，Kartagener 症候 群でみられる繊毛の異常は観察されなかった (図 4 ).上皮細胞下方の固有層には膠原線維が 密に存在し，軸索など神経線維の走行は全くみ

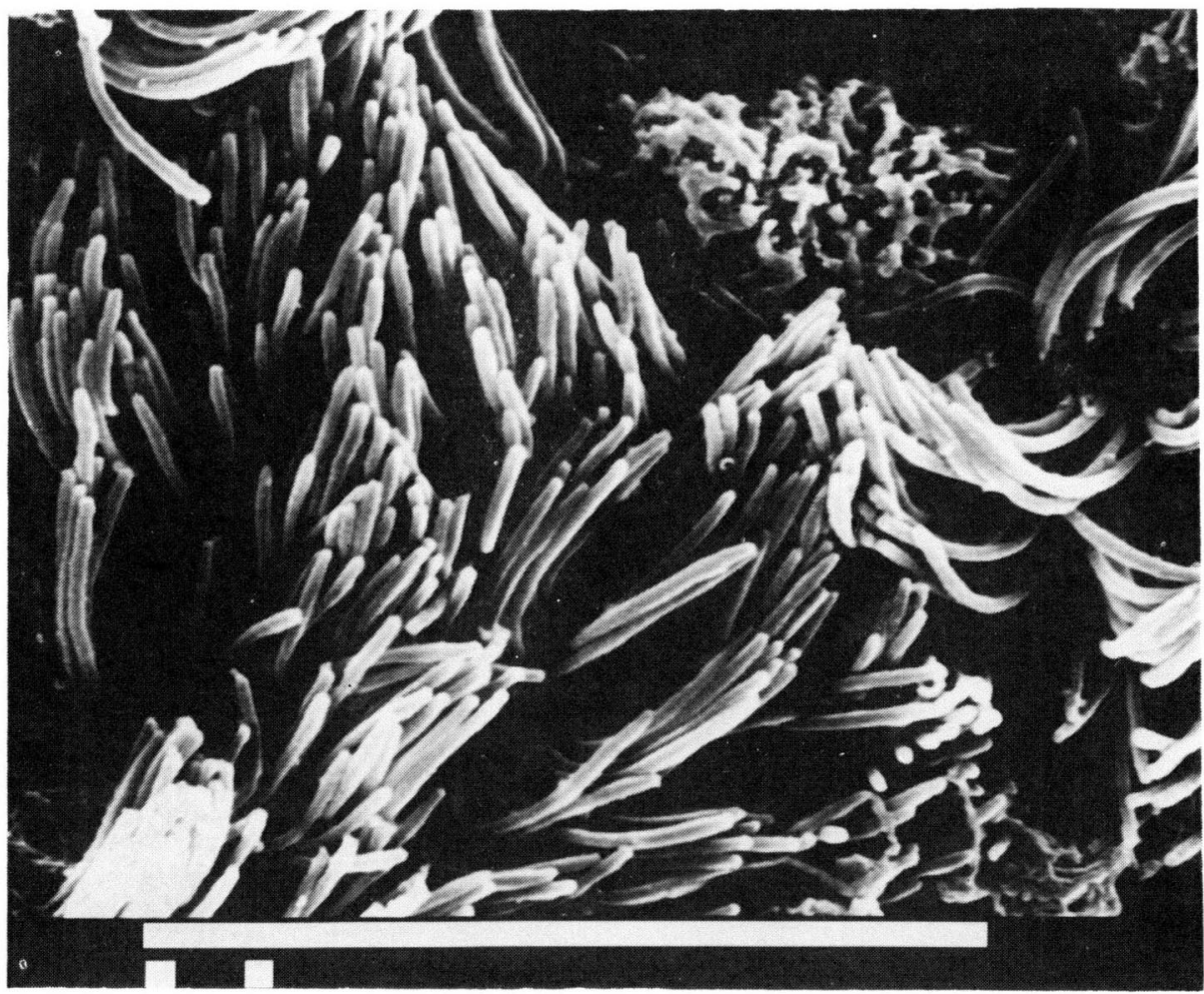

図 2 嗅裂部粘膜の表面

織毛と微絨毛および杯細胞から分泌された粘液で占められている $(\times 9300)$. 
られず，嗅細胞の再生，修復を思わせる所見は みられなかった（図 5 )。乙れらの所見は両側 嗅裂部に共通にみられ，電顕的所見からも嗅裂 部神経感覚上皮の形成不全が示唆された.

\section{考察}

これまで Kallmann 症候群についての本邦 での報告は 30 例を越え, 年々増加の傾向にあ る. 多くは泌尿器科領域で報告3) されており, 耳鼻科領域でこの疾患名を聞く機会は少ないの が現状である，家族内発生は $17 \%$ ，散発性は 83 \%と散発性が多く, 男女比では $25: 5$ と男性優 位の倾向を示している. 性染色体劣性遗伝や,
常染色体性遺伝などの推論むなされているが， いずれも確実な論拠はなく遗伝形式は明らかに されていない。平均発症年龄は男 25.8 歳, 女 25.3歳であるが, 実際, 二次性徽の発現する思 春期に発見することがむずかしいてと汇むよる と思われる。本症例は家系にはほかに同様の症 状を有する者はなく, 散発性発症に属すると思 われた。血中 L H , F S H，テストステロン低 下を示す性腺機能障害と hyposmia あるいは anosmiaに対して前者は男性ホルモンや蛋白 同化ホルモンの増量をはかり維持する療法が現 在の主流である，後者については，嗅球形成不

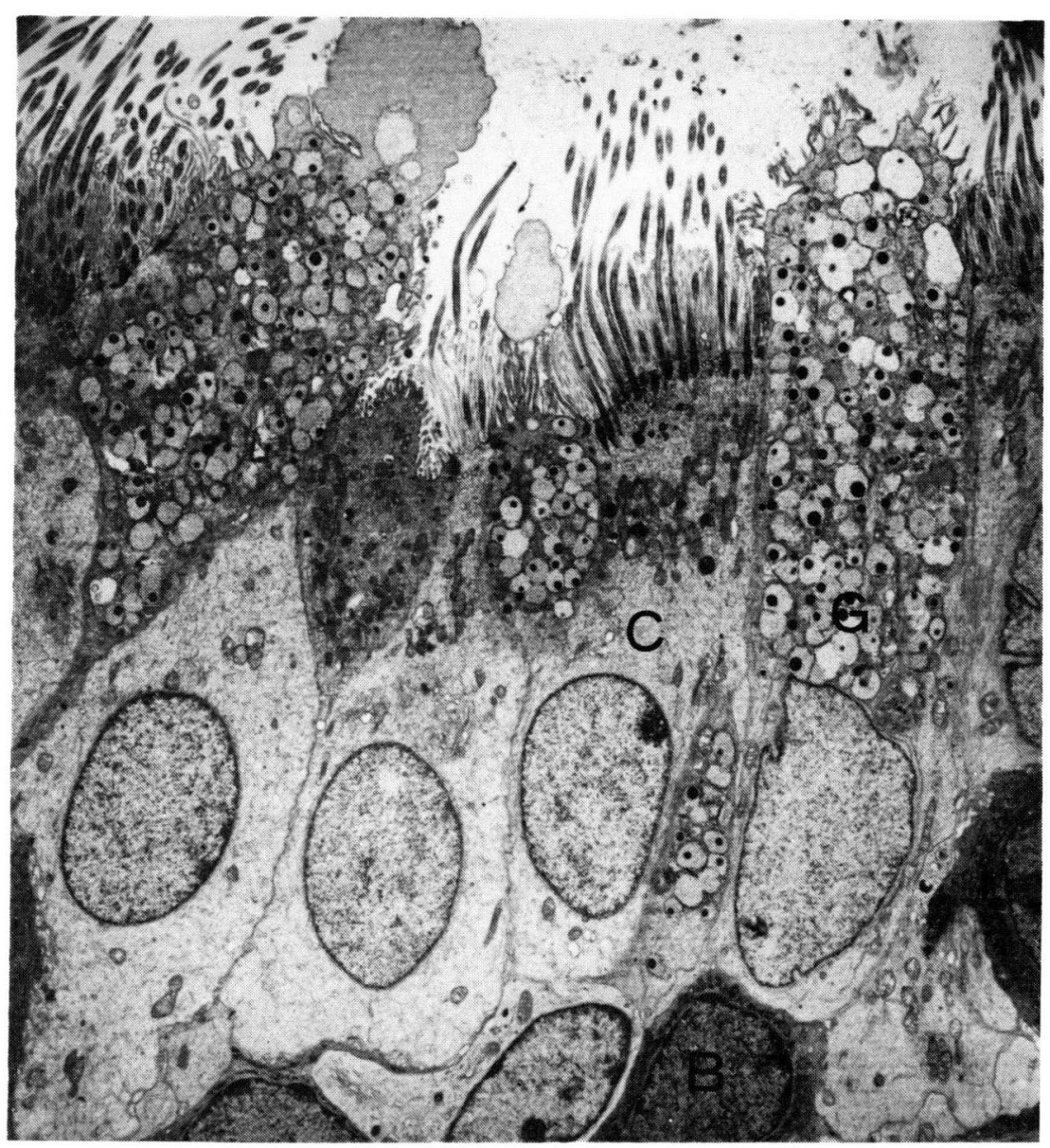

図 3 嗅裂部粘膜の横断面

織毛細胞 ( C), 杯細胞 ( G ), 基底細胞( B ) から成る呼吸上皮系の細胞配列を 示す. 嗅細胞は全く存在しない $(\times 3100)$. 
全が根底にあるとすれば，その治療は不可能に 近いと思われるが，今まで本邦で剖検された Kallmann 症候群は 1 例 $^{4}$ のみであり，他の多 くの Kallmann 症候群の嗅覚異常が同程度の 嗅球，嗅索障害によるものか否加は今な打不明 である．とりわけ本症候群における唤裂部の微 紐形態について䛉載した報告は今まで欧米の文 献にもなく，このたびのわれわれの報告が初め てと思われる。一般に，末佾感覚器官のなか で，嗅裂の神経感覚上皮は再生することが知ら れているが，Gradiadei ら は動物実験から嗅 神経切断後の咱細胞が基底細胞から再生するこ とを明らかにした。これらの事を考慮に入れる と，一度機能低下あるいは形態的変性をたどっ たとしても，条件さえ整えば，嗅細胞の再生， 軸索の進展, 再接合がおこり, 嗅覚の改善も不

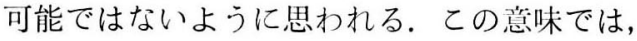

本症候群における嗅覚異常が完全な嗅覚啔失で はなく，多少と屯嗅覚の残っている嗅覚低下の 範盲にとどまっているなら，嗅細胞一嗅球一嗅 索一視床下部経路の連絡が低形成ながら保たれ ていると予想され，この場合に，ゴナドトロピ ンの早期投与·や神経賦活剂などの治療で嗅觉の 変化, 改善がおこりうるものか興味がもたれ る。本症例では，すでに完全な嗅覚坟失をきた して抢り，電顕的に屯嗅裂部神経感觉上皮の完 全な形成不全が网らかになった。したがって， 本症例の嗅覚の改善につながる治療方法は見い だせないが，嗅覚が幾分でも残っている症例に 対しては，嗅裂部感覚細胞の存在を確認するた め, 嗅裂部試験切除標本加ら病変の程度を検索 し，治療効果の上がる屯のであるのかを検討す る必要があろう。今後の引きつづく知見の蓄積 ととむに，この点が明ら加になってくるものと

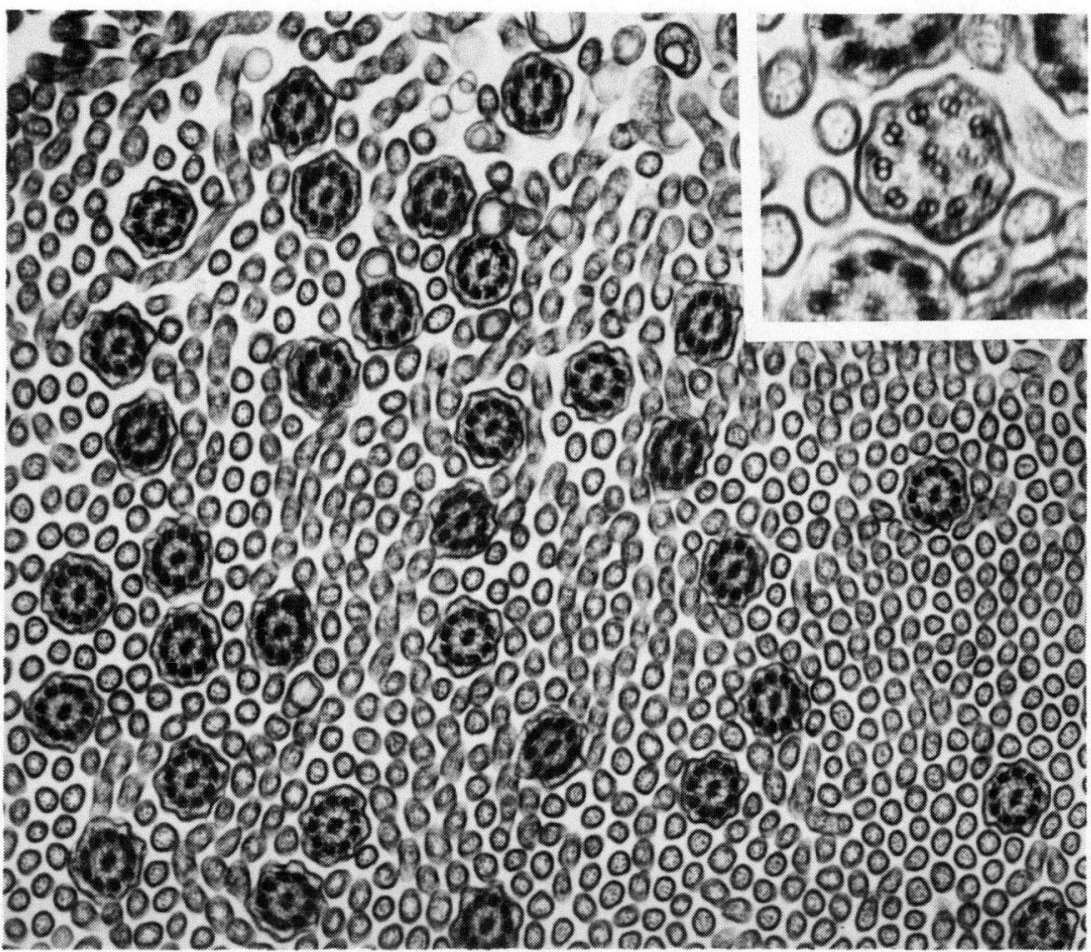

図 4 嗅裂部繊毛細胞の繊毛横断面

繊毛と微絨毛の配列と形態に異常はない $(\times 31000)$. 繊毛内の microtubule は $9+2$ の構造を示している（×76000）. 


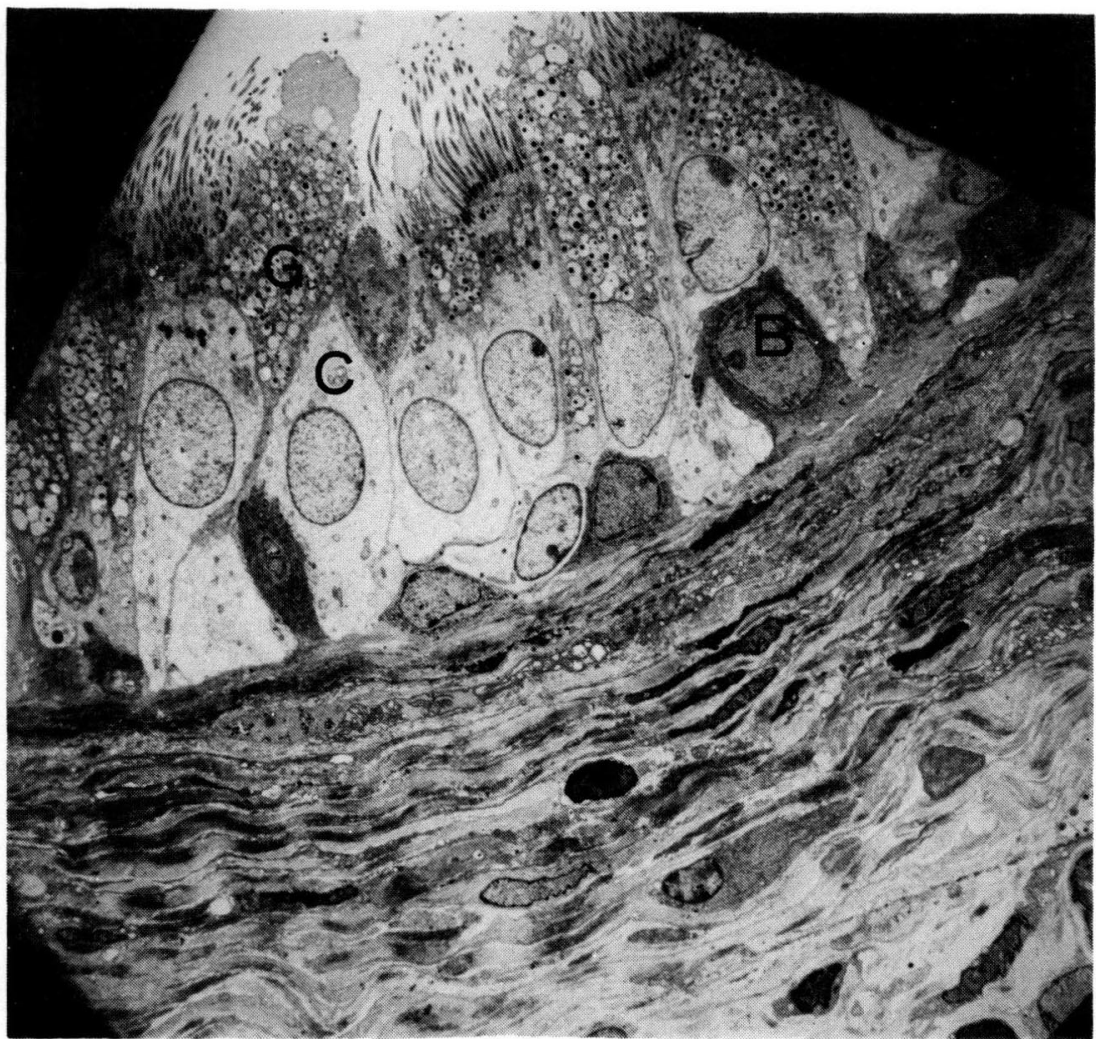

図 5 嗅裂部粘膜固有首

粘膜上皮細胞は呼吸上皮系細胞加成り, 固有層には神経線維の走行はみら れない. 繊毛細胞 $(\mathrm{C})$ ，杯細胞 $(\mathrm{G})$ ，基底細胞 $(\mathrm{B})(\times 1500)$.

期待される.

\section{まとめ}

低ゴナドトロピン性性腺機能低下と嗅覚の脱 失を伴なった，いわゆる Kallmann 症候群の 一症例を報告し，さらに嗅裂部より試験切除し た粘膜について電子顕微鏡的に検索した。二次 性性腺機能低下の臨床所見を有する52歳男性 で，生来，喚覚の自覚はなかった。両側嗅裂最 深部より小粘膜片を試験的に切除し，走査型お よび透過型電子顕微鏡で観察した。細胞の表面 には嗅毛や嗅小胞は存在せず，かわりに多数の 繊毛上微絨毛および粘液様分泌物がみられた。 細胞断面の特徴から，これら粘膜を構成する上 皮細胞は呼吸上皮之同様の繊毛細胞, 杯細胞, 基底細胞であった。一方，穆細胞やその変性・
再生像はどこにも観察されず，形態学的にも嗅 裂部感覚上皮の形成不全が示唆された.

\section{文献}

1) San Juan AM de: Falta totale de los nervios Olfactolriso con anosmia en un individuo en quien exista una atrophia congenita de los testiculos y miembro viril. Siglo $\mathrm{Me-}$ dico (Madrid) : 211 218, 1856.

2) Kallmann FJ, Schoenfeld WA and Barrera SE : The genetic aspects of primary eunuchoidism. Am J Ment Defic 48:203 236, 1944.

3）奥山明彦，板谷宏须，水谷修太郎，他：無嗅覚症 を伴なった低ゴナドトロピン性性腺機能低下症 （Kallmann 症候群）の 7 例. 日泌尿会誌 69 ： 
1654 1659, 1978.

4) 井坂勝利, 近森一正, 森 博愛: Kallmann 症候 群の 1 剖検例. 日内会誌 $68: 89 \sim 94,1979$.

5 ) Gradiadei PPC and Okano $M:$ Neuronal degeneration and rageneration in the olfactory epithelium of pigeon following transection of the first cranial nerve. Acta Anat 104 : 220 236, 1979.

$\left(\begin{array}{l}\text { 原稿到着: 昭和 } 60 \text { 年11月 } 18 \text { 日 } \\ \text { 別刷請求先 : 五十鵻 淑晴 } \\ \text { T173 東京都板橋区加賀 } 2-11-1 \\ \text { 帝京大学医学部耳鼻咽喉科学教室 }\end{array}\right)$ 